\title{
Can the new French economic policy be successful?
}

\author{
Catherine Mathieu and Henri Sterdyniak \\ Observatoire français des conjonctures économiques (OFCE), Paris, France
}

In early 2013, the French economy, like many other EU economies, faces tough challenges. French GDP is 9 per cent below the level it would have reached had it continued to grow at its pre-crisis trend. France has committed to cut the public deficit to 3 per cent in 2013 and 0 per cent in 2017 which would imply dramatic public spending cuts and fiscal tightening, reducing GDP growth even further. France has to choose between strengthening its specificity, its social model and its State-interventionist tradition, and imitating the best pupils of globalization in the world or in Europe by implementing liberal or social-liberal strategies. The paper deals with the French government strategy since the 2012 presidential elections and tries to assess its chances of success. In many areas - fiscal strategy, social issues, banking and industrial policies - there is a significant risk that the announced proactive strategy will be replaced by policies accepting the constraints imposed by European institutions and financial markets.

Keywords: French economic policy, fiscal compact

JEL codes: $E 65, H 60$

\section{INTRODUCTION}

In early 2013, the French economy, like many other EU economies, faces four main challenges. French GDP is still below its pre-financial crisis level and 9 per cent below the level it would have reached had GDP continued to grow at its pre-crisis trend. Between the first quarter of 2011 and the first quarter of 2013, GDP growth was almost flat. The unemployment rate has been above 10 per cent since the beginning of 2013 and has kept rising, with no sign of reversal.

The fall in output has led the public deficit to reach 5.2 per cent of GDP in 2011. Under the pressure of financial markets and EU authorities, France has committed to cut this deficit to 4.5 per cent of GDP in 2012 and to 3 per cent in 2013. This would imply a fiscal tightening of around 1.6 per cent of GDP in 2012 and 2.5 per cent of GDP in 2013. But such a tightening reduces GDP growth. The question is: How to escape from this spiral?

France suffers from problems in the manufacturing sector. The French current account turned from a surplus of 2.6 per cent of GDP in 1997 to a deficit of 1 per cent of GDP in 2007, and of 2 per cent of GDP in 2012. From 1997 to 2012, French market shares in world exports fell from 5.3 per cent to 3.3 per cent ( -38 per cent), in parallel with the experience of Italy and the UK, while German market shares declined only moderately ( -7 per cent). The central questions now are: How to restore the French productive structure? Is there a need for a 'competitiveness shock' to organize substantial transfers from households to companies? 
France has to choose between strengthening its specificity, its social model and its State-interventionist tradition, and imitating the best pupils of globalization in the world or in Europe by implementing liberal or social-liberal strategies. Yet, Europe suffers from low growth and is unable to exit from the crisis. Trade and financial globalization have initiated the 2007 financial crisis. Should France jump onto a train which is about to derail?

In May 2012, François Hollande, the socialist candidate, was elected President of the French Republic, and a coalition of socialists and greens won the legislative elections soon afterwards. This paper describes the strategy of the French government since these elections and tries to assess its chances of success. It shows that in many areas, there is a significant risk that the announced proactive strategy will be replaced by accepting the constraints imposed by the European institutions and financial markets.

\section{THE EUROPEAN STRATEGY}

The current state of EU economic governance is such that each Member State (MS) economic policy is constrained by European commitments which impose fiscal consolidation and liberal reforms. What policy measures may then a government elected on a social-democratic programme implement?

François Hollande wrote in his presidential manifesto in January 2012:' 'I want to reorient European construction. I will offer our partners a pact of responsibility, governance and growth in order to exit the crisis and the austerity spiral which aggravates it. I will renegotiate the EU Treaty, through favouring growth and employment, reorienting the ECB's role towards that direction'. In June 2012, François Hollande faced a major dilemma: signing the Fiscal compact meant accepting the liberal stance of the EU strategy; not signing the Fiscal compact meant opening a crisis in the EU.

\subsection{The fiscal compact ${ }^{2}$}

The fiscal compact (the Treaty on Stability, Coordination and Governance) strengthens the Stability and Growth Pact (SGP), although the latter was a failure. The fiscal compact is one more step forward both from liberal proponents against Keynesian economic policies, and from EU authorities against autonomous domestic fiscal policies. The Treaty aims at making the dream of the liberals come true: totally paralysing fiscal policies; imposing public budgets in balance at any cost.

According to the Treaty, budgets should be run in balance in structural terms, which has no economic justification. The true 'golden rule of public finances' ${ }^{3}$ allows

1. Proposal No 11 in François Hollande's manifesto, Le Changement c'est Maintenant - Mes 60 Engagements pour la France, January 2012: 'Je veux réorienter la construction européenne. Je proposerai à nos partenaires un pacte de responsabilité, de gouvernance et de croissance pour sortir de la crise et de la spirale d'austérité qui l'aggrave. Je renégocierai le traité européen issu de l'accord du 9 décembre 2011 en privilégiant la croissance et l'emploi, et en réorientant le rôle de la Banque centrale européenne dans cette direction.'

2. See also Bird/Mandilaras (2012) or Mathieu/Sterdyniak (2013).

3. This rule was developed at the end of the nineteenth century by Von Stein (1885), LeroyBeaulieu (1891) and Jèze/Boucard (1896). It can also be found for instance in Musgrave (1939) or Eisner (1989). 
governments to borrow to finance public investment. Besides, households, insurance companies and financial institutions wish to own a safe financial asset, like public debt, and consequently, a structural public deficit is required. Fiscal policy should aim at maintaining a satisfactory demand level, inducing the highest employment level consistent with stable inflation and an interest rate equal to the nominal growth rate: there is no evidence that the corresponding level of public deficit is nil. Since euro area MS do not control their interest rates and their exchange rate, they need degrees of freedom in terms of fiscal policies.

The Treaty imposes a rapid convergence towards the balanced budget in structural terms according to a trajectory to be set by the Commission without accounting for cyclical conditions. An automatic mechanism should be introduced to correct deviations from this trajectory. Temporary deviations should be allowed if they result from 'exceptional circumstances' or 'from a negative growth rate or from the accumulated loss of output during a protracted period of very low growth relative to potential growth', but corrective measures should be rapidly implemented. In fact the Commission refuses to recognize that euro area countries have been in such a situation since 2009 and insists on requesting rapid cuts in deficits.

The Treaty relies on the structural deficit concept. But its measurement is problematic, especially after strong macroeconomic shocks. ${ }^{4}$ In fact, the Treaty specifies that the Commission's estimates will have to be used. But they have two drawbacks. First, the Commission's potential output estimates are always close to observed output, because they consider as structural the reduction of the capital stock resulting from a fall in investment during the crisis, like a large part of the decline in potential labour force (due to unemployed people's discouragement), of the fall in productivity, and the rise in the unemployment rate: thus they underestimate the cyclical element of the deficit and will hence impose pro-cyclical policies. Second, these estimates are strongly revised over time. For instance, potential output estimates for 2006 were revised substantially downwards in 2008.

MS will have to introduce independent institutions in charge of verifying that the balanced budget rule and the convergence to the trajectory path are met. This is one more step towards full technocratic management of fiscal policy. ${ }^{5}$

A country under an Excessive Deficit Procedure (EDP) will have to submit its budgets and its structural reform programmes to the Commission and the Council, who will keep their implementation under surveillance. This article is a new weapon to impose automatic fiscal consolidation and liberal reforms.

The Commission's proposals will be adopted automatically unless there is a qualified majority against them, the country concerned not voting. Thus, in practice, the Commission will always have the last word.

The Treaty is based on an implicit but incorrect theory: automatic stabilizers should play, but discretionary fiscal policies to support activity should be prohibited. But such policies are needed to support full-employment (Lerner 1943 or Mathieu/Sterdyniak 2013). The fiscal pact aims at preventing any autonomous national fiscal policies. Fiscal policies should become automatic and aim at balancing budgets, just like monetary policy should aim at fighting inflation; growth and employment should be sought by liberal structural reforms.

4. See the method in D'Auria et al. (2010) and critical assessments in Mathieu/Sterdyniak (2011) or Truger/Will (2013).

5. On Independent Fiscal Committee, see Wyplosz (2002; 2011), Fatás (2003), Calmfors/ Wren-Lewis (2011) and Mathieu/Sterdyniak (2013). 
According to the Treaty, each country should run restrictive measures without accounting for its economic situation and for other MS policies. The Treaty assumes implicitly that restrictive policies have no impact on GDP. If we consider the situation in 2012, this implies that most countries run austerity policies even if their public deficits result from insufficient output levels following the burst of the financial bubble and not from structurally excessive spending.

\subsection{The growth pact}

In June 2012, France did not obtain any renegotiation of the Treaty, and merely obtained that the European Council adopted a Compact for Growth and Jobs. In spite of this title, it is not symmetric with the Fiscal Compact. It embeds no explicit target in terms of jobs or growth. It mostly includes already undergoing plans, some of them being of liberal inspiration: the Europe 2020 strategy, the need to guarantee the sustainability of pension systems, the improvement of the quality of public expenditure, the promotion of labour mobility, the fostering of competition in the areas of services, energy and public services. Growth-friendly measures are rather limited. An amount of $€ 120$ billion is mentioned ( 1 per cent of euro area GDP), but these measures apply over an undefined time period, and at a time when austerity programmes amount to $€ 240$ billion per year. Moreover, the impact of the promised $€ 120$ billion is questionable: $€ 60$ billion of it is supposed to come through an increase in the European Investment Bank's lending capacity thanks to a $€ 10$ billion increase in capital; $€ 5$ billion is supposed to be created by issuing Project bonds to finance infrastructure projects, and $€ 55$ billion will consist of already budgeted structural funds being re-allocated towards 'measures targeted to support growth'. The French government pretends to have obtained a major change in EU policies. In fact, the Compact for Growth and Jobs has not been integrated into the European major policies. The European Council decision from January 2013 to cut the European budget over the coming years marks the end of any hope of an active fiscal policy at the European level.

In fact, the French government ratified the Fiscal Pact to avoid creating a political crisis in Europe, fearing that this would block any progress towards financial solidarity and economic coordination in Europe and that it would lead to a new wave of financial market speculation which could force several southern countries to leave the euro. But the Fiscal Compact implies abandoning fiscal policy autonomy while EU policies will remain dominated by economic policies orthodoxy, and accepting a long fiscal restrictive period.

\subsection{The organic law}

The French government has chosen an ad minima reading of the Treaty, since the new fiscal procedure is not included in the Constitution, but only in an organic law. ${ }^{6}$ This law sets up a High Council of Public Finance, which will give its advice on macroeconomic forecasts underlying the budget laws. It will assess whether the budget is consistent with EU commitments and with the budget programming law. It will give its opinion on the existence of 'exceptional circumstances'.

6. In France, an organic law is intermediate between the Constitution and an ordinary law. It deals with government organization and rules. It must be agreed by the Constitutional Council. It requires an absolute majority in the Assembly. 
One may wonder what will be the degrees of freedom of the High Council. One may fear that the Council will not dare to conclude that the adjustment path is too restrictive or that the medium-term objective is not realistic. In the event of an economic slowdown, the Council will have to choose between promoting an expansionary policy to support growth and claiming for austerity measures to restore public finances.

The High Council is chaired by the President of France's Court of Audit (Cour des comptes), and consists of five members from the Court of Audit, the INSEE's Director, and five members appointed by the President of the National Assembly, the President of the Senate, the Presidents of the Finance commissions of the National Assembly and of the Senate, and the President of the Environmental, Economic and Social Council. The predominance of the Court of Audit in the Council is problematic. Its judicial officers are submitted to the hierarchical authority of their president; they are not macroeconomic experts, and are more concerned with public finance balance than with growth and employment. Among the 11 members of the Council, 8 will automatically be in favour of consolidation policies. Article 21 of the organic law states that the Council's deliberations will be confidential and that no minority view will be expressed in its reports.

Fiscal policy choices must be subject to democratic procedures. The assessment of economic policy belongs to scientific and democratic debates. It should not be entrusted to a High Council, consisting mainly of judicial experts, rather than economists on the one hand and representatives of the nation on the other.

The High Council will only give advice, which neither the government nor the parliament are obliged to follow, but there is a high risk that this advice will affect financial markets' and the European Commission's assessments and that it would be risky for the government to ignore it. A left-wing government should not have accepted handing over the conduct of the French fiscal policy to a technocratic-led authority, instead of an elected Parliament.

\section{THE ONE-EYED MACROECONOMIC STRATEGY}

In the presidential campaign, François Hollande announced that France would fulfil its commitment to bring the deficit down to 3 per cent of GDP in 2013 and to equilibrium in 2017 (Table 1). Thus he accepted the most arguable elements of the Pact - that is, a medium-term budgetary position in balance, and a trajectory of public balances independent of economic developments. Its programme implies a highly negative fiscal impulse in 2013 (-1.6 per cent of GDP) in order to reach the 3 per cent target; the fiscal impulse will remain negative afterwards, by around 0.6 per cent per year. François Hollande's programme differs from the right wing party's programme as strong increases in taxation are planned in the short term ( 2 per cent of GDP from mid 2012 to 2013); but it relies also on low public spending growth in the medium term.

This raises three issues:

1. It is debatable that a left-wing government durably exert downward pressure on public spending, knowing the needs for social (pensions, health, family, education) and economic (companies' support, public investment) spending.

2. The programme abandons the objective of filling the gap between current and pre-crisis trend output. Under the assumption that the output gap was close to -9 per cent of GDP in 2012, it would still be close to -7 per cent in 2017. 
Table 1 Macroeconomic prospects in François Hollande's programme

\begin{tabular}{lrrrrrrl}
\hline & 2011 & 2012 & 2013 & 2014 & 2015 & 2016 & 2017 \\
\hline GDP growth** & 1.7 & 0.5 & 1.7 & 2.25 & 2.25 & 2.25 & 2.25 \\
Government balance* & -5.2 & -4.5 & -3.0 & -2.3 & -1.6 & -0.8 & 0.0 \\
Interest payments* & 2.7 & 2.8 & 2.8 & 2.9 & 3.0 & 3.0 & 3.0 \\
Public expenditure* & 56.3 & 56.5 & 56.3 & 55.8 & 55.3 & 54.6 & 53.9 \\
Primary expenditure** & & 0.7 & 1.3 & 1.1 & 1.1 & 0.9 & 0.9 \\
Tax-to-GDP ratio* & 43.7 & 45.1 & 46.5 & 46.6 & 46.8 & 46.8 & 46.9 \\
Fiscal impulse* & & -1.5 & -1.6 & -0.6 & -0.6 & -0.6 & -0.6 \\
Neutral policy: fiscal impulse* & & & 0 & 0 & 0 & 0 & 0 \\
GDP** & & & 3.3 & 2.85 & 2.85 & 2.85 & 2.85 \\
Government balance* & & & -3.8 & -3.4 & -3.0 & -2.6 & -2.2 \\
\hline
\end{tabular}

Note: *As a percentage of GDP; **in $\%$.

Source: Hollande (2012: $40 \mathrm{fn} 2)$.

3. The macroeconomic consistency of the programme depends on the size of the fiscal multiplier. Let us assume that the multiplier equals 1 for a strictly French fiscal policy measure and 1.33 for a measure applied to the euro area. François Hollande's programme assumes implicitly that, in the absence of restrictive fiscal measures, GDP would have grown by 3.3 per cent in 2013 , and by 2.85 per cent from 2014 to 2017 (Table 1, last three lines). The programme abandons hopes of a growth rebound. It accepts that French GDP loses 4 per cent in 2017 in order to bring public finances into balance, while a public deficit of 2.2 per cent of GDP in 2017 would have been consistent with the true 'golden rule for public finances' and with public debt stabilization.

Let us consider the issue from another perspective: let us assume that France expects GDP to rise by 3 per cent in 2013, under neutral fiscal policies in the EU. The French public deficit will fall from 4.5 per cent to 4 per cent of GDP. In fact, the constraint is to bring the public deficit to 3 per cent. France should therefore implement restrictive policies amounting to 1 per cent of GDP. Since all euro area countries will do the same, the GDP growth forecast will be revised downwards to 1.7 per cent and the deficit will reach 3.67 per cent of GDP. There will therefore be a need for additional austerity measures of 0.67 per cent of GDP, etc. In the end, the successive austerity measures will result in a 3 percentage of GDP fiscal effort and a contraction of GDP of about 1 per cent.

\subsection{The 2013 budget}

In September 2012, the LPFP (Loi de Programmation des Finances Publiques) embeds slower growth in 2012-2013: the output gap estimate has been reduced to -1.1 per cent in 2012. The potential output growth estimate is 1.3 per cent only for 2012 and 1.6 per cent for the following years. The government has resigned itself to a slow growth path.

In the 2013 budget, the fiscal impulse is negative, by -2 per cent of GDP for 2013, of which 0.5 of a percentage point comes from expenditure cuts and 1.5 percentage 
points from higher revenues. The government bets on the assumption that increasing taxes on the wealthiest and on large companies will have a small impact on demand.

The number of civil servants remains stable: the rise in public service employment in some areas (education, police, justice, employment) is offset by cuts in other sectors. The general increase in public wages ( point de la fonction publique) remains nil. Some public investment expenditure (in culture, defence and justice) are cancelled. All in all, public expenditure cuts will amount to $€ 10$ billion. A strict management of public spending is pursued, albeit preserving the main functions of the State.

At the time of writing, in May 2013, the French economic outlook remains weak. GDP growth was nil in 2012, and, according to the OFCE or the European Commission, will be nil also in 2013. The public deficit will stand at around 3.7 per cent of GDP in 2013, clearly above 3 per cent, due to the low growth, which means that austerity policies will have to be pursued in 2014. In order to meet the balanced budget target in 2017, and with the commitment not to increase taxes any further, the government will have to cut public spending by $€ 70$ billion ( 6.5 per cent of current spending). The government seems ready to abandon its growth objectives, to reduce the support to French companies, to downsize the French social model, for an arbitrary goal of reaching a balanced public budget in structural terms. But the government estimates that it is tied by the European constraints and financial markets, and continues to run a restrictive fiscal policy albeit hoping (without saying it) that a softer fiscal stance will be agreed at the EU level.

\section{A RIGOROUS TAXATION POLICY}

François Hollande (2012: 15) wrote: 'I want to introduce a major tax reform. Each one's contribution will be made fairer by a major reform merging in the future the income tax and the CSG. Capital incomes will be taxed like labour incomes'.

A number of French economists and politicians advocate a major tax reform. But some advocate a strong reduction of the tax burden (which implies a corresponding decrease in public spending). Some propose to shift the social protection burden from companies to households, which is not possible without significantly lowering households' purchasing power and consumption? Others are in favour of a fairer distribution of the tax burden between labour and capital incomes, of increasing the degree of redistribution in the French tax-benefit system. But France already has one of the most redistributive systems, with relatively heavy taxes on the richest and on capital incomes. Some suggest a simplification of the French system, to abolish tax exemptions, to broaden the tax bases and to lower the tax rates. But they forget the incentive role of taxation. Many fiscal schemes, even complex, are justified for social fairness reasons, like the quotient familial ${ }^{7}$ or for job creation incentives, such as social contributions exemptions on low wages.

The French tax system has four characteristics as compared to its EU partners, and in particular with Germany (Table 2): France has two income taxes (IR, a progressive tax with many exemptions and complications, and CSG, a flat contribution upon all personal income), but their cumulated weight is relatively light, while property taxes are relatively heavy. Employers' social contributions are high; employee contributions are relatively low. The business tax (taxe professionnelle) is relatively heavy.

7. In the French income tax, the family income is split between each family member (a child counting for 0.5 ) before being submitted to the tax schedule. 
Table 2 Structure of taxation, in percentage of GDP in 2007

\begin{tabular}{lcc}
\hline & Germany & France \\
\hline Total & 37.3 & 42.4 \\
Personal income & 9.4 & 7.0 \\
Corporate income & 1.3 & 1.5 \\
Employees' social contributions & 6.3 & 4.1 \\
Employers' social contributions & 6.8 & 11.3 \\
Others' social contributions & 1.4 & 1.3 \\
Wage taxes & - & 1.3 \\
VAT and other indirect taxes & 11.1 & 10.6 \\
Business tax* & - & 1.5 \\
Taxes on capital & 0.9 & 3.4 \\
Households' local tax & & 1.1 \\
Households' property tax & 0.2 & 0.7 \\
Company property tax & 0.3 & 0.6 \\
Wealth tax & - & 0.2 \\
Inheritanceldonation & 0.2 & 0.4 \\
Transactions & 0.2 & 0.4 \\
\hline
\end{tabular}

Source: OECD (2012).

Capital taxation is relatively high, while consumption taxation is rather low. Of course, there is no reason why French taxation should be brought in line with taxation in other EU countries. It is normal to have high social contributions in a country where social insurance benefits are high. The high level of employers' contributions is partly offset by the level of net wages. However, these figures would suggest that France should increase the weight of its income tax and VAT, and should reduce employers' social contributions $;^{8}$ in other words, it should implement a strategy of competitive internal devaluation, which is problematic in the EU context.

In 2012-2013, the government's strategy is to move towards a fairer taxation, weighing more on large companies, on the financial system and wealthiest households, and abolishing some tax cuts that the conservative president Nicolas Sarkozy (and even Jacques Chirac) had implemented, in particular abolishing some tax exemptions. The government faces a difficult trade-off: increasing taxation on the wealthiest people and the largest companies is consistent with its aim of tax fairness; it may have a smaller impact on demand than taxation on the whole population, but, in an open economy, it introduces risks of losses of competitiveness and attractiveness and of tax optimization and tax evasion behaviours.

Table 3 shows the measures taken by the government for 2012-2013, which amount to $€ 32$ billion per year ( $€ 11$ billion on firms or banks, $€ 11$ billion on the richest households, $€ 10$ billion on all households).

Concerning the business sector, the government has not introduced measures to reduce corporate taxation on SMEs or on reinvested profits, owing to public finance constraints and contrary to what François Hollande had announced. The corporate tax rate on large companies thus remains at 36 per cent, which is the highest level in Europe (the euro area average is 26 per cent).

8. This strategy is advocated in OECD (2013). 
Table 3 Tax measures decided by the new government (billions of euro, for a full year)

\section{Households Among which Firms/ Indirect} higher incomes banks taxes

2 percentage points increase in capital income social contribution $^{\mathrm{a}}$

End of tax exemption for overtime

Social contribution on participation, profit-sharing

Bank taxation

Social contribution on non-residents

Increase in wealth tax rates

Increase in inheritance taxation

Financial transactions tax

Increase in pension contributions

Measures against firms' tax optimization

Income tax rate at $45 \%$ and $75 \%$

$\begin{array}{lll}+2.6 & +2.6 & \\ +4.0 & & +0.5 \\ +1.4 & +0.5 & +1.5 \\ & & +0.55 \\ & & +0.5 \\ +0.25 & +0.25 & +1.2 \\ +1.2 & +1.2 & \\ +1.4 & +1.4 & \\ +0.25 & +0.25 & +0.25 \\ +1.5 & & +1.2 \\ & & +1.5\end{array}$

Decrease in the family fiscal reduction ceiling $^{\mathrm{b}}$

Non-indexation of the income tax schedule

Ceiling on tax expenditure

Taxation of dividends, interests and financial gains at the income tax schedule

Increase of taxation of real-estate gains

Taxation of $20 \%$ of firms' interest pay-

$\begin{array}{lll}+0.5 & +0.5 & \\ +0.5 & +0.5 & \\ +1.3 & +0.9 & \\ +0.4 & +0.4 & \\ +1.4 & +1.0 & \\ & & \\ +0.7 & +0.6 & \\ & & +3.4 \\ & & +1.0 \\ & & -0.2\end{array}$

Taxation of companies' capital gains

Increase in the R\&D tax credit

$-0.2$

Ecological taxes

Individual workers' social contributions

$+1.3+0.7$

Social contribution paid by households as employers

Wage tax ${ }^{\mathrm{c}}$ increases

$+0.3 \quad+0.3$

Excises on beer

Pensioners' contribution for old-care social assurance

Total: 32

\begin{tabular}{llll} 
& & +0.8 & \\
+0.7 & & & +0.8 \\
+20.1 & +11.1 & +11 & +1.0 \\
\hline
\end{tabular}

Notes:

${ }^{a}$ In France, capital incomes pay social contributions to finance universal and assistance benefits. ${ }^{b}$ Due to the quotient familial system, families with children benefit from a tax reduction. The benefit has a ceiling, which was $€ 2336$ per child in 2012 . The ceiling was reduced to $€ 2000$, to increase taxation on richer families.

${ }^{\mathrm{c}}$ Some sectors (like the financial sectors) do not pay VAT but are subject to a wage tax. 
Concerning income taxes on top earners, the tax rate now stands at 41 per cent for incomes above $€ 71000$ and 45 per cent for those above $€ 150000$. Due to an exceptional contribution, the tax rate is increased to 48 per cent above $€ 250000$ and 49 per cent above $€ 500$ 000. But employees also have to pay a CRDS-CSG contribution, and their employers pay health and family contributions (which have no ceiling). The 45 per cent income tax rate hence translates into an effective tax rate of 60.2 per cent on higher wages, and the 49 per cent tax rates into an effective tax rate of 63.25 per cent; which are among the highest rates in Europe (45 per cent in the UK, 47.5 per cent in Germany, 62 per cent in Sweden, 66 per cent in Belgium). In the 2013 budget, the French government introduced, as announced by François Hollande, a tax rate of 75 per cent on wages above $€ 1$ 500000 per annum. But this was denied by the Constitutional Court as it was calculated on an individual basis, and not on a family one. But the Government plans to reintroduce it, paid by the firms who pay such high wage-levels.

Interest income payments bear a 15.5 per cent tax rate, as a social contribution, plus income tax rates. Under a nominal interest rate at 4 per cent, and inflation at 2 per cent, the real income will be 2 per cent and is taxed at a 108.8 per cent rate (for a person at the marginal income tax rate of 41 per cent). Dividends and capital gains are taxed at the personal income tax rate, after a 40 per cent rebate, which accounts for the fact that dividends have already been taxed at the corporate tax; so the dividends' effective tax rate (for a person at the marginal income tax rate of 41 per cent) is in fact 60.9 per cent. It is hard to imagine a tax reform which would make the system more redistributive.

Thus, the government decision to cut the budget deficit through measures focusing mainly on richer households and larger firms leads to a heavy and redistributive tax system. ${ }^{9}$ This is rational after a crisis which has shown the risk in terms of economic stability introduced by increases in incomes inequalities. However, it is not clear whether France, isolated in Europe, will be able to maintain this specific taxation structure.

The strong rise in capital gains taxation was strongly opposed by entrepreneurs who threatened to reduce their operations in France or to leave it altogether. In April 2013, François Hollande made a U-turn: the rebate on capital gains was increased from 40 per cent to 65 per cent (and even 85 per cent for start-ups and for entrepreneurs retiring). The government has sacrificed its tax fairness objective to a reconciliation objective with entrepreneurs.

\section{SOCIAL POLICY}

On the whole, France has until now maintained a high level of social protection, which leads to fewer income inequalities and lower poverty rates than in Mediterranean and Anglo-Saxon EU countries; and without deteriorating equality like in the Nordic countries or Germany ${ }^{10}$ (Table 4).

There was no strong commitment in François Hollande's programme in terms of wage growth or social benefits increases. The minimum wage was increased by 2 per cent in July 2012, but this brought forward the automatic increase induced by inflation,

9. Nevertheless, some authors (like Bozio et al. 2012 or Landais et al. 2011) still consider that France could undertake a comprehensive tax reform in order to make the tax system even more redistributive.

10. This was highlighted in OECD $2011 \mathrm{~b}$. 
Table 4 Poverty rates in Europe

\begin{tabular}{lcccc}
\hline & 1997 & 2007 & 2010 & Variation 2010/1997 \\
\hline Germany & 12 & 15.2 & 15.6 & +3.6 \\
Austria & 13 & 12 & 12.1 & -0.9 \\
Belgium & 14 & 15.2 & 14.6 & +0.6 \\
France & 15 & 13.1 & 13.5 & -1.5 \\
The Netherlands & 10 & 10.2 & 10.3 & +0.3 \\
Spain & 20 & 19.7 & 20.7 & +0.7 \\
Greece & 21 & 20.3 & 20.1 & -0.9 \\
Italy & 19 & 19.9 & 18.2 & -0.8 \\
Portugal & 22 & 18.1 & 17.9 & -4.1 \\
Denmark & 10 & 11.7 & 13.3 & +3.3 \\
Finland & 8 & 13 & 13.1 & +5.1 \\
Sweden & 8 & 10.5 & 12.9 & +4.9 \\
Ireland & 19 & 17.2 & 16.1 & -2.9 \\
UK & 18 & 18.6 & 17.1 & -0.9 \\
\hline
\end{tabular}

Source: Eurostat.

such that the 'coup de pouce' (increase in purchasing power) was only 0.6 per cent. The September school benefit (allocation de rentrée scolaire) was increased by 25 per cent, but this was financed by lowering the quotient familial ceiling.

The government does not plan to increase family benefits and the RSA (Revenu de Solidarité Active, the minimum income benefit) more rapidly than the consumer price inflation rate, although these price-indexed benefits have been losing purchasing power relative to average earnings over recent years, which has increased the poverty rate among families. In December 2012, the prime minister promised to progressively increase the RSA by 10 per cent, and to increase benefits for poorer single parents or families with many children. But, in February 2013, the prime minister asked Bernard Fragonard, the head of Family High Council, to make proposals to cut family benefits by $€ 2.2$ billion until 2016, as a contribution to public spending cuts. This would require jeopardizing the generosity and universality of the family benefits, even if the French system is recognized as one of the most efficient in the OECD countries (OECD 2011a).

In June 2012, the right to retire at 60 has been restored for workers who started work at the age of 18 or 19 and who have paid contributions for at least 42 years (otherwise the retirement age would have been 62 for people born in or after 1955). This measure is expected to increase the number of pensioners by 140000 and cost $€ 2.8$ billion (partly offset by a $€ 0.8$ billion decrease in unemployment benefits). The measure will be financed by a 0.5 percentage point increase in the social contribution rate (equally split between employees and employers) that will raise $€ 2.7$ billion.

The economic crisis has worsened the pension system financial situation, which ran a deficit of around 0.7 of a percentage point of GDP in 2012. Pension expenditures are expected to increase from 13.5 per cent of GDP in 2008 to 15 per cent in 2050 (assuming a continuing fall in the pension/wage ratio, by 18 per cent in 2050) or even to 17 per cent (if replacement rates are stabilized). The government plans to launch a large debate on a pension reform in 2013. There is a risk of deteriorating the pension system under the pretext of ensuring its sustainability. Like employers, 
the government refuses to increase social contributions rates further. It plans to reduce the pension system deficit by removing pensions' price-indexation and by postponing the retirement age, which is problematic in a situation of mass unemployment and is not in line with the Socialist party programme.

\section{EMPLOYMENT POLICY}

In early 2013, the French unemployment rate reached 10.6 per cent. In the absence of GDP growth, the unemployment rate increases by one percentage point per year. With the potential labour force growing by 0.6 per cent per year, and accounting for firms' labour-hoarding during the crisis, GDP would need to grow by an annual 3.2 per cent to bring the unemployment rate to 7 per cent within 5 years.

Young people have been particularly affected by the crisis. The employment rate in this group fell by 3.5 percentage points, while the unemployment rate rose by 2.5 percentage points (Table 5). Conversely, older workers' activity rate rose sharply by 8.7 percentage points, of which 1.8 percentage points are due to a rise in the unemployment rate and 7.0 percentage points to a rise in the employment rate. The retirement age continues to be postponed, but, in crisis times, the price seems to be paid by young people.

In order to reduce youth unemployment, the French government plans to create 150000 'jobs for the future' (emplois d'avenir). The government finances 75 per cent of the costs of the jobs created for a period of 1 to 3 years for unskilled young people in the nonmarket sector, and preferably in areas expected to expand (green jobs, care, tourism, new technologies). At the same time, the 'contrats de génération' scheme will encourage firms to simultaneously recruit a young (below 25) employee, while maintaining in employment an older employee (aged over 57). According to the OFCE's estimations (see Allègre et al. 2012; Heyer/Plane 2012), these schemes will create 200000 jobs at the end of 2014, which is not enough to stop the increase in the unemployment rate.

President Hollande aims at reforming the labour market and social protection through a social dialogue between trade unions and employers. A 'social conference' took place in July 2012 and a social roadmap was established. Social dialogue will be enshrined in the Constitution. The challenge is that France abandons a State-leading model to move towards a social democratic model (with peaceful relations between trade unions and employers, with mutually beneficial agreements) rather than towards the liberal model (where unions' role is denied). But this reform is not easy to introduce in times of rising unemployment, when firms want more flexibility in terms of lay-offs, worked hours and wages, and unions want more security and more control on lay-offs.

In January 2013, the employers' organization (the Medef) and three (out of five) employees' trade unions signed an agreement, the ANI (interprofessional national

Table 5 Employment in young and old people, since 2008

\begin{tabular}{lccccccccr}
\hline & \multicolumn{3}{c}{$15-25$ years old } & \multicolumn{3}{c}{$25-49$ years old } & \multicolumn{3}{c}{$55-65$ years old } \\
\hline Rates & $2008-\mathrm{Q} 1$ & $2012-\mathrm{Q} 3$ & & $2008-\mathrm{Q} 1$ & $2012-\mathrm{Q} 3$ & & $2008-\mathrm{Q} 1$ & $2012-\mathrm{Q} 3$ & \\
Employed & 31.9 & 28.4 & $-11.0 \%$ & 83.5 & 80.9 & $-3.1 \%$ & 37.9 & 44.9 & $+18.5 \%$ \\
Unemployed & 6.6 & 9.1 & $+37.9 \%$ & 5.7 & 8.0 & $+40.4 \%$ & 1.7 & 3.5 & $+106.0 \%$ \\
Active & 38.5 & 37.5 & $-2.6 \%$ & 89.2 & 88.8 & $-0.5 \%$ & 39.6 & 48.3 & $+22.0 \%$ \\
\hline
\end{tabular}

Source: INSEE. 
agreement), which will facilitate lay-offs, internal flexibility and agreements between workers and employers cutting working hours and wages to maintain jobs in case of firms' difficulties. In exchange, the agreement discourages part-time jobs with very few hours or with very short contract duration and generalizes supplementary health insurances. For many economists, companies will hire more easily since they will be no longer paralysed by the fear of not being able to lay off. For others, there is a risk to increase the precariousness of employment. Nevertheless, both the government and the trade unions involved in the deal seem to accept the liberal view according to which labour market rigidities explain the unemployment level in France (as expressed in Cahuc and Zylberberg 2009; European Commission 2013; OECD 2013) and not macroeconomic disequilibria.

\section{BANKING POLICY}

In January 2012, François Hollande declared: 'My enemy is the world of finance'. In his programme, he had committed himself to 'split banking activities useful to investment and jobs from their speculative activities' and to create a public investment bank (Banque Publique d'Investissement, BPI) to support small and medium-sized firms. The doubling of the ceiling of regulated saving accounts was supposed to allow the financing of public banking activities.

The BPI was created in November 2012 but its importance and rule are not yet settled. On the one hand, the BPI will have regional branches where social partners and regional authorities will attend. On the other hand, there is a risk that the BPI will be managed only from a financial perspective, that the BPI managers wish to show their independence and refuse to support jobs and innovation. The BPI should have been given precise and non-standard management criteria. Last, the BPI is expected to be allocated only $€ 3$ billion per year, which is a very limited amount.

France approves of the European banking union project, thus putting the supervision and regulation of its domestic banking sector in the hands of EU authorities. But in the European project, banks are requested to diversify internationally, thus losing contact with their country, companies, and government administration. The risk is that governments depend even more on financial markets in the future. Bank lending capacity will depend on their equities and on markets' valuation and not on the needs of the economy. Governments will lose their capacity to have an impact on the banks' credit supply, which is desirable according to some views (no political interference in credit), but is dangerous in our view (governments will lose an industrial policy tool which could be used to finance SMEs or to boost environmental transition). This project, based on open competition and free market rules, comes in contradiction with the establishment of the BPI and, also, of a public bank to finance French local government.

If the government were true to its proclaimed aims, France should have supported a different project: restructuring the banking sector, with banks having to focus on their core business (lending, based on a specific expertise, to national or local companies, households and the local administration). Their solvency would have been ensured, not by financial ratios, but by forbidding them to run risky or speculative operations and by public support.

In early 2013, France adopted a 'law of separation and regulation of banking activities', intended to implement François Hollande's commitment. However, in fact, the government has refused to question the French model of universal banking. Speculative 
activities, narrowly defined, will not be forbidden to retail banks, but they will have to be put in a separate financial subsidiary. The Law demands banks to run separately their 'unrelated to customer service' market activities. However, banks can continue to run operations 'that have proved useful for the economy'. But the notion of utility is not questioned. Is the development of financial activities useful? Should banks induce non-financial agents to use toxic loans, structured products and derivatives? Similarly, the term customer has not been specified as not to apply to hedge funds and certain investment funds. Thus, the following activities remain allowed even after the reform: financial services provision to customers (for hedging), coverage of the institution's own risk (interest rate risk or credit risk), implementation of structured financial products such as derivatives activities and market-making activities. Hedge fund ownership is prohibited, as well as unsecured loans to these funds, but so-called secured loans remain allowed. In total, the project will only isolate 2 per cent of the banking business.

Speculative activities will have to be confined to an autonomous financial subsidiary, which will not be guaranteed by the parent company (and therefore by public money), will be financed independently, able to go bankrupt, and will have to develop a resolution plan showing that its bankruptcy may be supported by its creditors. Moreover, the 'Prudential control and resolution authority', PCRA, may prohibit certain activities and the Minister of Finance may require banks to limit the size of financial operations carried out by the parent company.

It may seem strange to introduce such a law on topics that will perhaps no longer be of national relevance in 2 years when the EU Banking union is settled. It raises once again the question of the relationship between decisions at the national and at the European level. For example, the PCRA may prohibit certain activities, according to French law; but how, if these activities remain authorized at the banking union level? Will the Minister of Finance still have some authority over banks in 2 years?

\section{AN AMBITIOUS INDUSTRIAL POLICY}

The French economy suffers from a rising trade deficit due to the weakness in the manufacturing sector. François Hollande's programme was insisting on the need to 'relaunch production, employment and growth'. Four policies were put forward:

1. establishing the BPI;

2. supporting small and medium-sized enterprises (SMEs), especially through extending the R\&D tax credit (Credit Impôt Recherche), increasing orders from the public sector, the BPI, a single public interlocutor for declaration, taxes and subsidies;

3. taxing international relocation (French companies relocating production abroad), supporting companies investing, producing and relocating in France, reducing corporate taxes for SMEs, introducing different tax rates for dividends and reinvested benefits;

4. implementing a new trade policy in Europe by fighting against unfair competition, by implementing reciprocity agreements on social and environmental areas and by decreasing the euro's exchange rate vis-à-vis the dollar and the yuan.

The new government has a ministry for productive revival (ministère du redressement productif) with representatives appointed in each region in order to support companies 
in difficulty. The BPI is designed to finance innovative companies. The Minister wishes to re-value the label 'made in France', to make clear that France produces high quality and environmentally friendly products and to develop economic 'patriotism' by pushing households to buy French products.

At the EU level, France would like the Competitiveness Council to evolve and implement an industrial policy, allowing public support to innovating firms or to threatened sectors, and a more protectionist trade policy.

Thus the French strategy would involve the government in a substantial role. The government would guide industrial development towards green and innovative products and production techniques. It would decide on the sectors to be protected and the sectors to be developed. These sectors would receive support through taxation, specific aids (investment, innovation), and the BPI. The productive revival would be piloted by the ministry, the BPI, regions, social partners, and not only by firms' managers or owners. This strategy is hardly consistent with EU constraints and with the functioning of a capitalist system. It requires motivating workers in concerned companies, civil servants in its ministry, bankers in the BPI, politicians in the regions, and companies' managers to impel a new growth model, which is not an easy task.

\subsection{A competitiveness shock?}

In view of the deterioration of the French economic performance, many (among them the MEDEF, the employers' association, and also the CFDT, a reformist employees' trade union) advocate a competitiveness shock. The plan is to cut employers' contributions, and, as a counterpart, to increase households' taxation, via VAT or CSG. In February 2012, the former government had decided such a measure at a limited scale, cutting employers' contributions by $€ 13$ billion, financed by a rise in VAT ( $€ 11$ billion) and a rise in taxes on households' capital gains ( $€ 2$ billion). The measure was to be introduced by 1 October 2012. Following the Presidential elections, the new government abolished this measure when it came into power, but asked Louis Gallois, former head of EADS, who had expressed his opinion in favour of the competitiveness shock, to prepare a report on this topic (Gallois 2012).

The 'competitiveness shock' philosophy is that households accept a strong fall in purchasing power in order to improve companies' profitability or competitiveness. In fact, there is little difference between increasing CSG or VAT. However, a rise in VAT increases price inflation, and this automatically affects the minimum wage rate (SMIC), and social benefits, which are fully price-indexed and - after wage bargaining - other wages, which means that the gain in terms of companies' competitiveness and profitability may be short-lived. On the contrary, the victims of a rise in CSG would not benefit from indexation rules and would have to accept a lower purchasing power. The project raises five issues, were the current government to embark on it:

1. The government would have to request households to accept a fall in their incomes. This would be in contradiction to the decision to abolish the VAT increase which had been announced by the former government.

2. There are no companies' commitments, in terms of investment and jobs in France, in exchange for a measure that would substantially increase their profits. There is a risk that the companies would increase their dividends or investment abroad.

3. France is in an intermediate position between northern countries which have improved the competitiveness and profitability of their firms at the expense of 
domestic households' purchasing power, and southern countries where wage growth was excessive. It would be catastrophic for the euro area if France followed the German strategy: this would induce each MS to cut wages and social benefits with a view to improving domestic competitiveness leading domestic consumption and thereafter GDP - to fall.

4. French companies' profit share in value added stood at 29.6 per cent in 1973. It fell to 23.1 per cent in 1982, and rebounded to 30.2 per cent in 1987. It stood at 30.8 per cent in 2006 - that is, at a satisfactory level. Since then the ratio has fallen, due to the fall in output and labour hoarding, which in principle is a temporary phenomenon. The fall was not caused by taxation or by excessive wage increases. The profit share in value added will not be restored with the introduction of measures leading consumption (and hence GDP) to decrease.

5. Using internal devaluation assumes that France suffers mainly from a pricecompetitiveness deficit. But, de-industrialization has other and deeper roots. Companies prefer to expand their activities in emerging countries, scientific education is not a first choice, the young refuse to start a career in manufacturing because job prospects appear to be too risky and wages are too low. France has succeeded neither in protecting its traditional industries, nor in developing innovating sectors. This would not be solved by internal devaluation.

Despite these challenges, the government decided on November 2012 to take a first step towards a competitive real devaluation. From 2014, companies will benefit from a tax credit for competitiveness and employment (CICE) of €20 billion, calculated as 6 per cent of their wage bill for wages between 1 and 2.5 times the minimum wage. These $€ 20$ billion will be financed by $€ 10$ billion obtained by additional cuts in public expenditure; by $€ 7$ billion from a VAT rise and by $€ 3$ billion from an increase in ecological taxation in 2016. This tax credit is not subject to any condition, but companies will have to establish a report showing that these tax credits were used for investment, employment or R\&D. These $€ 20$ billion amount to a mere 2.5 per cent cut in total wage costs; only one-third will benefit industry. One may fear that the government will more or less abandon any active interventionist industrial strategy to promote a liberal policy - that is, to increase firms' profit in praying that they will invest.

\section{CONCLUSION}

François Hollande's economic strategy is ambiguous. The French President was convinced that there is a need for a new policy in Europe that was more growth-targeted, but in order to avoid a political crisis in Europe, he accepted the Fiscal Pact which forces member states to run austerity policies. This imposes an absurd trajectory of public deficit cuts on France, which makes fiscal policy pro-cyclical. Public deficit reductions are expected to be obtained in the short term by higher taxation on the wealthiest and on large companies, but in the medium term by public and social spending cuts of 3 per cent of GDP. The European discourse on the need for structural reforms is neither clearly accepted nor clearly rejected. The government counts on social partners to reform labour markets, choosing the employers' viewpoint (higher flexibility) rather than the trade unions' one (preventing lay-offs). He wishes both to reassure financial markets and to reduce their influence (in particular through banking regulation and financial transaction taxation). François Hollande is in favour of a strict separation between retail and investment banks, and for an increasing role of the investment public bank (the BPI). But he 
accepts the European banking union, where France would lose all control of its banking system. The French banking law is very limited. The government wants to organize a 're-industrialization' of the French economy, through direct support by the government, regions and the BPI to industrial firms. But the resources allocated to this policy are limited. The BPI is under-funded. The government does not organize the social mobilization needed for a reform of corporate governance. Under the pressure of entrepreneurs' organizations, the government undertook a 'competitiveness shock' strategy, a decrease by $€ 20$ billion employers' social contributions financed by public expenditure cuts and VAT increases. The risk of this ambiguity is that the government will not convince firms' managers and entrepreneurs, after the tax rises in 2012-2013; it will not mobilize workers, disappointed by the lack of social measures, the continuation of austerity policies, the shyness of economic strategy and the continued rise in unemployment.

In mid 2012, two scenarios could have been envisaged. The first was a 'rupture scenario', where France would try to find an original way, Colbertist, social-democrat and ecologist, based on public and social intervention, boosting growth, protecting the French social model and social cohesion, preparing for environmental transition. France would have had to find allies in Europe to implement such a strategy, with the risk of breaking up the euro area. The second was the 'normalization scenario': France agrees to implement progressively all EU measures, at the risk of a long recession and rising unemployment, and allowing the French social model to deteriorate. Progressively, the Ayrault government is choosing the second scenario. It is unlikely that wages and public spending austerity and liberal 'structural reforms' will provoke a growth revival in France. The French left will surrender without having even fought.

\section{REFERENCES}

Allègre, G., Cochard, M., Plane, M. (2012): Quels effets du contrat de génération sur l'emploi et les finances publiques?, in: Revue de l'OFCE, No HS-2012, 35-42.

Bird, G., Mandilaras, A. (2012): Will Europe's fiscal compact help avoid future economic crises?, Working paper, School of Economics, University of Surrey.

Bozio, A., Dauvergne, R., Fabre, B., Goupille, J., Meslin, O. (2012): Fiscalité et redistribution en France, 1997-2012, mimeo, IPP.

Cahuc, P., Zylberberg, A. (2009): Les Réformes Ratées du Président Sarkozy, Paris: Flammarion.

Calmfors, L., Wren-Lewis, S. (2011): What should fiscal councils do?, in: Economic Policy, 26(68), 649-695.

D’Auria, F., Denis, C., Havik, K., McMorrow, K., Planas, C., Raciborski, R., Röger, W., Rossi, A. (2010): The production function methodology for calculating potential growth rates and output gap, European Economy Economic Paper, 420.

Eisner, R. (1989): Budget deficits: rhetoric and reality, in: The Journal of Economic Perspectives, 3(2), 73-93.

European Commission (2013): Macroeconomic imbalances, France 2013, European Economy Economic Paper, 136.

Fatás, A., Hallett, H., Sibert, A., Strauch, R., Von Hagen, J. (2003): Stability and Growth in Europe: Towards a Better Pact, London: CEPR.

Gallois, L. (2012): Pacte pour la Compétitivité de l'Industrie Française: Rapport au Premier Ministre, Paris: La documentation française.

Heyer, E., Plane, M. (2012): Les emplois d'avenir: quel impact sur l'emploi et les finances publiques?, in: Revue de l'OFCE, No HS-2012, 43-44.

Hollande, F. (2012): Mes 60 engagements pour la France, Paris, Parti socialiste, January.

Jèze, G., Boucard, M. (1896): Cours de la Science des Finances et de la Législation Financière, Paris: V. Giard et E. Brière. 
Landais, C., Piketty, T., Saez, E. (2011): Pour une Révolution Fiscale, Paris: Le Seuil.

Lerner, A.P. (1943): Functional finance and the federal debt, in: Social Research, 10(1), 38-51. Leroy-Beaulieu, P. (1891): Traité de la Science des Finances, Paris: Guillaumin et Cie.

Mathieu, C., Sterdyniak, H. (2011): Finances publiques, sorties de crise, in: Revue de l'OFCE, $116,17-60$.

Mathieu, C., Sterdyniak, H. (2013): Do we need fiscal rules?, in: The Euro Area in Crisis/Revue de l'OFCE, Debates and Policies, 127, 189-233.

Musgrave, R. (1939): The nature of the budgetary balance and the case for a capital budget, in: American Economic Review, 29(2), 260-271.

OECD (2011a): Doing Better for Families, April.

OECD (2011b): Divided we Stand: Why Inequality Keeps Rising, December.

OECD (2012): Public Revenues Statistics, November.

OECD (2013): Economic Studies: France, March.

Truger, A., Will, H. (2013): Open to manipulation and pro-cyclical: a detailed analysis of Germany's 'debt brake', in: The Euro Area in Crisis/Revue de l'OFCE, Debates and Policies, $127,155-188$.

Von Stein, L. (1885): Lehrbuch der Finanzwissenschaft, Leipzig: F.A. Brockaus.

Wyplosz, C. (2002): Fiscal discipline in EMU: rules or institutions?, mimeo, April.

Wyplosz, C. (2011): Fiscal discipline: rules rather than institutions?, NIESR Review, 217(1), $19-30$. 